\title{
The Theory and Application of Blended Learning
}

\author{
Li Ning \\ School of Foreign Language, Yan'an University \\ Yan'an, China \\ lorna0_1982@163.com
}

\author{
Gao Zhi dong \\ School of Foreign Language, Yan'an University \\ Yan'an, China \\ 270855728@qq.com
}

\author{
Qin Xiaomei \\ School of Foreign Language, Yan'an University \\ Yan'an, China \\ 453650577@qq.com
}

\begin{abstract}
Blended learning as a combination of traditional and on line learning has aroused educators' great attention, but its definition, the theoretical foundation, the concrete application need to be studied further. This paper aims to make teachers and students have a better understanding about blended learning, analyzing the definition, the theory, teaching practice, influences on the teacher-student relationship and the most barriers in blended learning by the method of questionnaire and interview. Although the result shows some obstacles that need to be overcomed by teachers and students, blended learning will be accepted as an effective approach to maximum the classroom efficiency in the digital world.
\end{abstract}

Keywords-Blended learning; Constructivism; Assessment; New teacher-student relationship; Challenge

\section{INTRODUCTION}

With the rapid development of information technology, the approach and means of teaching, the model of learning in higher education have changed a great deal. Traditional (faceto-face) learning was criticized seriously because of missing individual learner's needs and ignoring support to problem solving and critical thinking [1-3]. On line learning are also not satisfying due to "lack of peer contact and social interaction, high initial costs for preparing multimedia content materials, substantial costs for system maintenance and updating, as well as the need for flexible tutorial support"[4]. Blended learning tries to make a combination of traditional and online learning [1-3]. Thorne [5] thinks blended learning is the integration between e-learning and face-to-face instruction. A.Y. AlQahtani et al [6] states "In the current study blended learning took the form of a combination of face-to-face classroom teaching with lecture and class formats and the use of an asynchronous online classroom". D. C. Duhaney [7] takes blended learning as a combination of the use of electronic learning tools (software, email, World Wide Web including video and/or audio streaming, television, voice mail, conference call) and traditional face-to-face classroom teaching strategies/techniques to ensure maximum effectiveness. There is no doubt blended learning can make on line learning and traditional learning supplement mutually, which is regarded as a promising alternative learning approach. This paper tries to explore the theory blended learning based on, teaching management, teaching practice and new teacher-student relationship and the most challenges for teachers and students under the model of blended learning.

\section{CONSTRUCTIVISM: THE BASIS OF THE BLENDED LEARNING}

The model of blended learning requires the teacher to change the role of lecturing, play as the role of designer and guide providing the effective assistance. From the constructive perspective, it means teachers should practice the role of "scaffolding" that creating meaningful connections between teachers' cultural knowledge and the everyday experience and knowledge of the students. If teachers are clear about their roles, they also need scaffolding in "the zone of proximal development" proposed by Russian psychologist Vygotsky, the area between the child's current development level "as determined by independent problem solving" and the level of development that child could achieve "through adult guidance or in collaboration with more capable peers"[8], thus teachers should try to figure out students' zone of proximal development, the area that is neither two easy nor two difficult. It requires teachers know more about students' current abilities and how to provide certain assistance. Teachers must be aware which problems students can solve on their own; which problems beyond students' capabilities that even if teachers explain in detail, step by step, students are still in confusion; which problems students can deal with if the teachers give them some instructions, help, clues or reminders. Learning should occur just in this "magic middle" -somewhere between what the students already know and what the students aren't ready to learn.

Unlike Piaget who cares more about learning between peers Vygotsky also stresses learning between teachers and students. Students construct knowledge by themselves, but the significant role of teachers as "scaffolding" in cognitive development can not be neglected. This concept completely fulfill the ideal of blended learning " students-centered, teacher-oriented". Students could make full use of online material to construct their own understanding, thus teacher playing the role of "scaffolding" would answer the questions and explain the difficulties in face-to-face classroom teaching. 


\section{TEACHING PRACTICE: PREPARATION - ACTIVITY - REFLECTION}

Before class, teachers should hand out the guide of how to preview, related reference books, collect all the useful related teaching materials on line, even can design some pre-class quiz. Students are required to preview all the reading material, skim the website and watch relevant video, they also should ask some questions and provide the difficult points in the learning. Firstly peers can talk online trying to solve the problem, and then teachers collect the representative questions to discuss further in face-to-face classroom. All the modern technology aims to provide effective assistance to maximize the teaching efficiency. A fundamental view of blended learning shows that the online learning should be considered as a value-added component instead of a replacement of traditional classroom learning to better serve their students [9]. So students can preview the teaching material well with the assistance of on line learning.

In class, the activity is the core of the blended learning, teachers should design the effective classroom activities and manage the process of operating the activities which aims to improve the teaching efficiency and makes the atmosphere of class active. Teachers should help students to answer the questions they met in the period of previewing, the approach of problem-based could arouse the students' curiosity, teachers also can set up some situations to create an appropriate "disequilibrium". In order to arouse the students" interest, collaborative learning is really appreciated, students can benefit from exchanging of explanations, elaborations, questions and activities. In class, students' main task is to participate actively in the all kinds of teaching activities.

Flipping classroom is another means to improve the interaction of teachers and students. Students have freedom to choose the teaching materials they are interested in, to arrange learning time on line freely, thus through communicating with teachers and peers in face to face classroom the knowledge learning on line could be internalized.

After class, such as online grade book, online assignment submission, and online supplemental materials may provide a significant extent of convenience for students. All the teachers and students should seek feedback, to reflect the merit and shortcoming of the class, try to improve the teaching efficiency further. This step could be realized with the help of modern technology, such as webchat, e-mail, the platform of MOOCs and soon. This step is very important, but is always neglected by teachers and students, teacher can hand out the questionnaire to get students' reflection, and then do the statistical analysis.

According investigation and teaching experiences, students prefer learner-centered, problem-based, and team-based approaches over instructor-centered [10], the model of blended learning just can fit into students' preferences.

\section{TEACHING MANAGEMENT: FORMATIVE AND SUMMATIVE ASSESSMENT}

In a blended learning environment, formative and summative assessment must be put into practice together, especially formative assessment cannot be ignored. Teachers should construct scoring scheme to quantify students' performance online and in classroom, because some students cannot manage themselves very well, they need to be motivated by scoring, only those who can regulate themselves highly and accept responsibility willingly are more effective learners, the others are less effective learners who need to be monitored. The greater autonomy that e-learning offers, the more challenges for the e-learner to self-regulate.

With the modern teaching platform, such as MOOCs, teachers can trace students' behavior, habit, efficiency of learning, then quantify their learning activities. Scores also need to be used in classroom teaching to motivate students to participate in the classroom activities; all the activities taking in the learning can be quantified. As formative assessment is defined in the Third International Conference on Classroom Assessment, "Assessment for Learning is part of everyday practice by students, teachers and peers that seeks, reflects upon and responds to information from dialogue, demonstration and observation in ways that enhance ongoing learning. [11]"

Formative assessment can motivate students to perform well on line and in classroom teaching, gradually students would be used to asking and answering questions, seeking help, valuing the teamwork and pursuing feedback. It is worthwhile to note feedback also has strong impact on ongoing learning, teachers should continuously reflect students' learning state, teachers and students need to establish the mode of feedback.

The formative assessment aims to guide the teacher in planning and improving instruction, even changing teaching plan, while summative assement could let teachers and students have a general understanding about the accomplishment attained. Summative assessment could be used to evaluate student's performance in final exam, its aim is to know the level of accomplishment for teachers and students, thus teachers and students could have a general evaluation of their performance.

Actually formative and summative assessment are two aspects of assessment, they are not completely separated with each other. Any type of assessment like test, performance, project can be used for either formative or summative purposes. Therefore, teachers should combine them together to form the basic and whole grasp of students' learning.

\section{NEW TEACHER-STUDENT RELATIONSHIPS IN BLENDED LEARNING}

In the past students only can get to know their teacher when teachers come into classroom, but in the modern digital world students may already know the brief introduction of the teacher, have read the articles written by the teacher, ever watch some video listening to the teachers' class. It means probably students already have am impression of the teacher 
before joining the classroom, teachers not only need to care their image in the classroom but also the image on line.

In the past, teachers in China are authoritative, they are the "giver" of the knowledge, students are the "receiver", the teaching model is that teachers talk the whole class while students listen passively. With the assistance of modern technology, the teaching model is changed, during the teaching process, they are exploring and constructing together. Knowing well about the teaching material is not enough; teachers should think about how to design and manage the whole class, they are designer and mangers.

In the model of blended learning, the communication between teachers and students is broken up with the limitation of time and space, it can take place anywhere at anytime, therefore teachers can reflect students' question and provide effective assistance on line in time. Teachers not only transfer the knowledge but accompany the students to develop mentally and physically, they are partners of learning.

\section{Challenges for teachers and students}

The model of blend learning requires teacher to work as designer, guide and cooperator which is a great challenge for teachers who are used to traditional teaching style. They have to change teaching concept, even some teachers should be trained again to continue the career of teaching. A lot of time and energy would be occupied by thinking of how to design classroom activities, how to learn students' needs and individual difference, and how to reflect student's performance on line and in face-to-face classroom. Teachers' attitude and devotion to blended learning will influence the teaching efficiency greatly.

Teachers have different cognitive understanding about the definition and models of blended learning, thus it's hard to form the same evaluation of the teaching. For some aged teachers, it is a great challenge for them to use digital resources. Technology is a big obstacle for them to apply the model of blended learning, they complain it consumes too much time but turns out a little, even think blended learning is just a kind of fashion, just the revolution of the form in the learning, never touch the basic teaching concept.

For the department of the teaching management, they need to spend a large sum of money to set up the environment of blended learning, such as build up the teaching platform, train the teachers and students to adopt the new teaching approach and buy some digital resources, but to keep up pace with the modern educational technology, it's worthwhile to invest money in information technology, and the availability of technical support would significantly influence teachers' and students' decision of adopting it .

For Chinese students, it seemed they have adapted to traditional teaching style, some of them are unwilling to be active in class. Some students think it takes them too much time to prepare before class. Blended learning as a new model aroused the global interest, students should change their mind and do their best to be adjusted to this kind of teaching environment in the digital world.

\section{CONCLUSION}

Although there are many elements to restrict the model of blended learning, the students belong to the digital generation, they spend a lot of time using the mobile and computer, so it's reasonable and necessary to establish the model of on line learning, whereas traditional classroom teaching has its nonalternative advantage as "live lecture". On balance, blended learning takes the advantage of the benefit of online and faceto-face setting, which has been accepted as an effective approach to integrate synchronous and asynchronous technology together to maximum the classroom efficiency, change teacher-student relationships and cultivate students' ability to construct knowledge themselves.

\section{ACKNOWLEDGMENT}

This article is a partial result of "Construction and Practice of College English KACIA Curriculum System (17BZ033)" funded by Shaanxi Provincial Education and Teaching Reform Project (2017), also has received the finical support from the Educational Science and Planning Foundation of Shaanxi Province (Grand No. SGH17H061), the Social Science Foundation of Shaanxi Provincial Education Department (Grand No.16JK1844) and the Projects of Yan'an University (Grand No. KGZD2017-03, Grand No.YDJG2016-22).

\section{REFERENCES}

[1] B. Banathy. "Designing educational systems: Creating our future in a changing world". In C. M. Reigeluth and R. J. Garfinkle, Eds., Systematic change in education. Englewood Cliffs, NJ: Educational Technology Publications, pp.27-34, 1994.

[2] S. D. Johnson, S. R. Aragon, N. Shaik, and N. Palma-Rivas. "Comparative analysis of learner satisfaction and learning outcomes in online and face-toface learning environments". Journal of Interactive Learning Research, vol.11, pp. 29-49, 2000.

[3] W. Hannum, and L. Briggs. "How does instructional system design differ from traditional instruction”. Educational Technology, vol.22, pp. 9-14, 1982.

[4] J. H Wu, R. D. Tennyson, T. L. Hsia, and Y. W. Liao. "Analysis of elearning innovation and core capability using a hypercube model". Computers in Human Behavior, vol. 24, pp, 1851-1866, 2008.

[5] K. Thorne, "Blended learning: How to integrate online and traditional learning. London”. UK: Kogan Page, 2003.

[6] A. Y. Awadh Al-Qahtani, and S. E. Higginst. "Effects of traditional, blended and e-learning on students's achievement in higher education". Journal of Computer Assisted Learning, vol.29, pp. 220-234, 2013.

[7] D. C. Duhaney. "Blended Learning Education, Training, and Development". Performance Improvement, Vol.43. Septembe 2004.

[8] L. S. Vygotsky. "Mind in Society: The Development of Higher Psychological Processes". Cambridge, MA: Harvard University Press, 1978.

[9] A. Y. Chou, and D. C. Chou. "Conceptual Article Course Management Systems and Blended Learning: An Innovative Learning Approach, Decision Sciences". Journal of Innovative Education, Vol. 9, pp.463-484, September 2011.

[10] K. J. Kim, C. J. Bonk, and E. Oh. "The present and future state of blended learning in workplace learning settings in the United States". International Society for Performance Improvement, vol. 47, pp. 5-16, September 2008.

[11] N. Z. Dunedin. "Third International Conference on Assessment for Learning (TICCA)". Position paper on assessment for learning. March 2009. 